\title{
NATURAL FIBERS AND BIOPOLYMERS CHARACTERIZATION: A FUTURE POTENTIAL COMPOSITE MATERIAL
}

\author{
LALIT Ranakoti $^{1 *}$, MAYANK Pokhriyal ${ }^{1,}$, ANKUR Kumar ${ }^{1}$ \\ ${ }^{I}$ Department of Mechanical Engineering, National Institute of Technology Uttarakhand \\ *email: lalit_9000@yahoo.com
}

\begin{abstract}
Now days, green composite materials are now gaining popularity for the various industrial applications. It is a combination of naturally occurring reinforcement like jute, sisal, flax, hemp, and kenaf; and matrix materials like biopolymers or bio resins which have been derived from starch, and vegetable oils. It is becoming more desirable due to its properties like biodegradability, renewability and environment friendly. The present paper presents the various natural fibers and their combinations with biopolymers. The paper also reflects the key issue related to hydrophilic nature of natural fibers and their remedies for a good fiber and bio polymer adhesion. Furthermore the strategy used and major attributes of the green composite are also discussed.
\end{abstract}

KEYWORDS: natural fibers, biopolymers, chemical treatment, green composite

\section{$1 \quad$ Introduction}

Composite material has wide spectrum in industrial and engineering fields using suitable material like metal [1-2], polymers and ceramics so as to obtain optimum strength, these materials are being used according to the growing need of the society. Transition of Industries towards production of green composite is taking place due to the increasing demand of consumer, to reduce the use of synthetic material, higher sustainability, biodegradability, friendly to environment and recyclability, inexpensive, low density etc. [3, 4]. Natural fibers are biologically occurring materials which have two main sources (a) agriculture production and (b) production residue of crops when they are processed for the primary uses [5]. Typically known natural fibers are wood, silk, ramie, jute, hemp, kenaf, sisal, coir, flax, bamboo and fruit fibers. Natural fibers are majorly used with thermoplastics and thermoset plastics. Thermoplastics and thermoset plastics both are non-bio degradable but thermoplastics are recycled in an easy manner as compared to thermoset. The use of natural fiber with the above said plastics does not result in fully biodegradable composite but incorporation of natural fibers with the bio degradable matrix like PLAs, polyglycolic acid (PGA), poly-b hydroxyalkanoates (PHA), and poly caprolactone (PCL), makes it a fully biodegradable composites. Natural fibers have other advantages like mechanical properties such as tensile strength and elastic modulus of natural fiber composite better than the plain polymer [6]. Non toxicity, low energy consumption and absence of disposed options are other beneficial advantages of natural fibers. Besides these favourable properties of natural fibers, their applications are still very few and the same trend is following for the natural fiber bio degradable composites. This may be due to the fact that natural fibers on the whole are somehow found inferior to the synthetic fiber when talking about the mechanical properties [7, 8] but work is still going on to increase the mechanical properties of natural fibers. Moreover the compatibility of natural fiber with the polymer is also a big issue due to the hydrophilic nature of the natural fiber. Mechanical properties of natural fiber and their compatibility with polymer can be increased with the help of physical and chemical methods. 
In physical methods like corona discharge, sputtering, calandering, low temperature plasma, stretching, thermal treatment etc. [9] the structural properties of natural fibers are altered which results in increasing the mechanical bonding between fiber and polymer. Chemical methods include some popularly known treatments such as graft copolymerization, silane treatments, alkali swelling, cyanate treatment, impregnation of fibers, etc. which results in enhancement of the adhesion between the fiber and polymer. For the expansion of natural fiber in various industries, the present paper unearths the physical, chemical and mechanical properties of natural fiber, their combination with various bio polymers. Further various methods used to increase the adhesion properties of the fibers and the technique used for the manufacturing of composites are also discussed in the present paper. The application of natural fiber in various industrial fields has been shown in figure 1. The diagram shows that more than $65 \%$ of natural fiber composite has application in packaging industries and remaining $35 \%$ has application in medical, textiles, electronic and agriculture with the percentage of 4, 8, 4, 6 respectively [10].The paper published in the field of natural fiber can be seen in figure 2. It can be seen that the number of paper published are increasing with the year. As the pattern of published paper is ever increasing there is need of review of the research work carried out by the researchers.

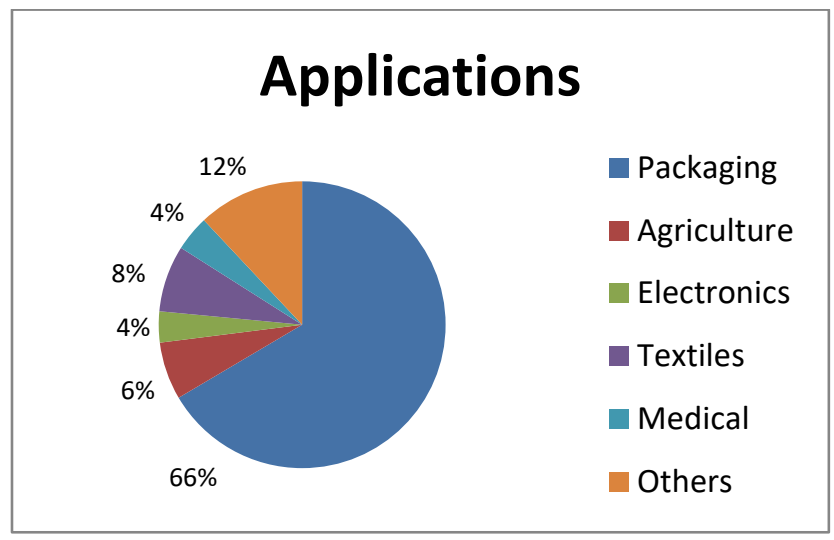

Fig. 1 Application of Natural fibers in various Industries

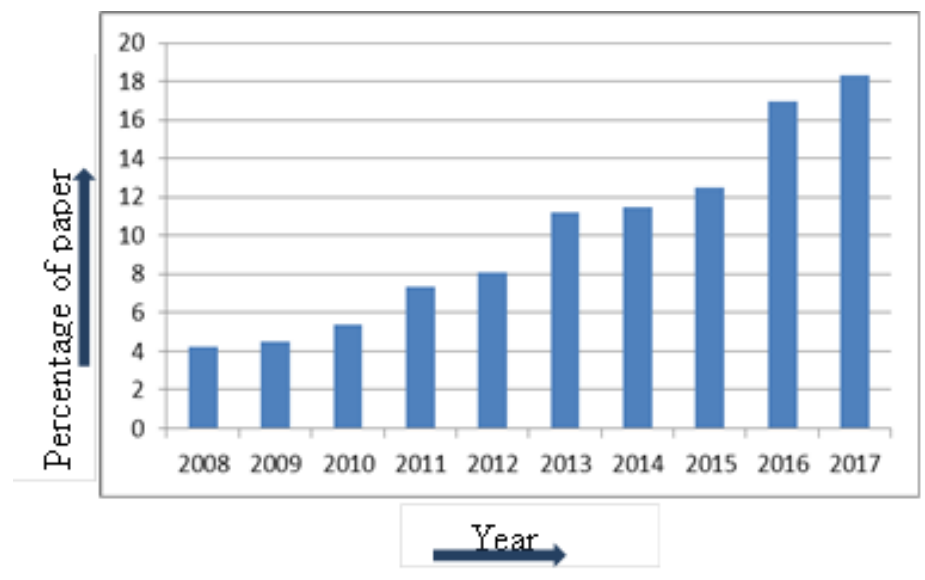

Fig. 2 Publication of research paper in natural fibers composite in last 10 years

\section{Natural fiber}

Fiber is the reinforcement used to bear the load transferred through the matrix. They provide strength and stiffness to the polymer [11,12]. Fibers are obtained either naturally and man-made. Naturally occurring fibers can be classified in three main categories i.e. animal fiber, mineral fiber and plant fiber as can be seen in figure 3. Animal fibers are those which 
are obtained from animals for example hairy mammal, sheep wool, got hair, silk etc. [13]. Silk fiber is also an animal fiber which has highest tensile strength among all the natural fiber [14]. Mineral fibers are naturally occurring or slightly modified fiber produced from mineral. Asbestos and ceramic are commonly known mineral fibers. Mineral fibers are capable of working in high temperature conditions [15]. These can also be used as refractory material. Plant fibers are the most abundant fiber among all the natural fiber. Hemp, Himalayan nettle, sisal, jute, kenaf, flax, abaca, ramie etc. are the commonly known plant fiber. Plant fibers are also called cellulosic fiber and have quite promising tensile strength [16]. Reinforcement of natural fiber is compatible with both thermosetting and thermoplastics. Epoxy, polyester, polyurethane, phenolic, etc. are some common plastics which are in use today in the manufacturing of natural fiber composites requiring higher performance applications particularly stiffness and strength. But these composites are accompanied with the inherit demerit of composting which is now one of the biggest issue for the present generation. Natural fiber bio polymer composites, on the other hand do not have the problem of composting and there is a compromise between the strength of the composite and the composting problem. Several ways have been identified to increase the strength of the natural fiber bio polymer composite to develop a composite which can replace the current synthetic polymer composite. Areca fiber is a perennial crop. It is an inexpensive, highly abundantly crop and easily available. It is mainly composed of hemicellulose and high rate of moisture sorption [17]. Thus areca needs to be treated before using it for making composite to reduce the moisture absorption [18]. Kenaf fiber is a cellulosic fiber. It has both economic and ecological advantage as it can be grown in varied environment and the growth of the plant is very much promising [19]. It is extensively used fiber due the lower rate of moisture sorption which makes it a compatible fiber for most of the polymer matrix [20]. Banana fiber composed of mainly carbohydrates and protein makes it a high strength fiber but it has content of water uptake. Thus initial treatment is also needed for the banana fiber [21]. Similar properties are inherited by the sisal, hemp, jute, oil palm, pineapple, coir, flax, ramie, Himalayan nettle etc. [22-26, 27, 28]. For the development of green composite fiber selection is critical and needs to possess good mechanical properties such as stiffness and tensile strength. Some other properties like failure elongation, thermal stability, fibers and matrix adhesion, dynamic and over lasting behaviour, low manufacturing cost and rate of moisture absorption are also important for the selection of fiber. Considering the natural fibers, some properties are found better than the synthetic fibers such as inexpensive, elevated mechanical characteristics, better heat insulation, insulated to acoustics and bio-degradability. As an example Sisal is a natural fiber can be used with flax fiber and biopolymer resin resulted in good permeability of composite [29]. As we compared the properties of natural fibers (Table 1) like tensile strength and specific modulus with synthetic E glass fiber, it can be conclude that hemp and flax fiber has the potential to compete with synthetic fiber. Chemical properties of the typically known plant fibers which are now extensively being used as reinforcement can be seen in Table 2. Observation shows that mainly cellulose, hemicellulose, lignin, and pectin $[30,31]$ are found in varying proportion in plant fibers. Moreover, some item which are non-structural such as waxes, inorganic salts and nitrogenous substances are also included in the Table 2. These chemical properties are affected by the following reasons. These are: climatic conditions, degradation, age and time taken by the fiber while growing, floral classification and the stalk height [32]. Chemical properties of natural fiber have their own significance while selecting fiber for the fabrication of composite. The chemical properties make the basis of predicting the final properties of fiber polymer fabricated composite. The chemical constituents of natural fiber greatly affect the properties like physical, mechanical, thermal and tribological of composite materials when used as reinforcement. Cellulose influences the strength of the fiber, lignin which acts as cementing materials influences its 
structure and morphology, waxy substances influences the wettability and adhesion characteristics. Hence, it is desirable to sort out these obstacles by treating the fiber with certain chemical methods to improve the surface properties of fiber, wettability, compatibility of fiber. The chemical treatment enhances the properties of fiber by reducing the moisture content which generally found in the range from $8-12.6 \%$ before treatment. The strongly polarized cellulosic fibers inherently are less compatible with hydrophobic polymers. Hence by the introduction of third materials (coupling agents), compatibility between fiber and polymer can be enhanced as it eliminates weak boundary layers, deformable layers, wettability, chemical bonding etc.

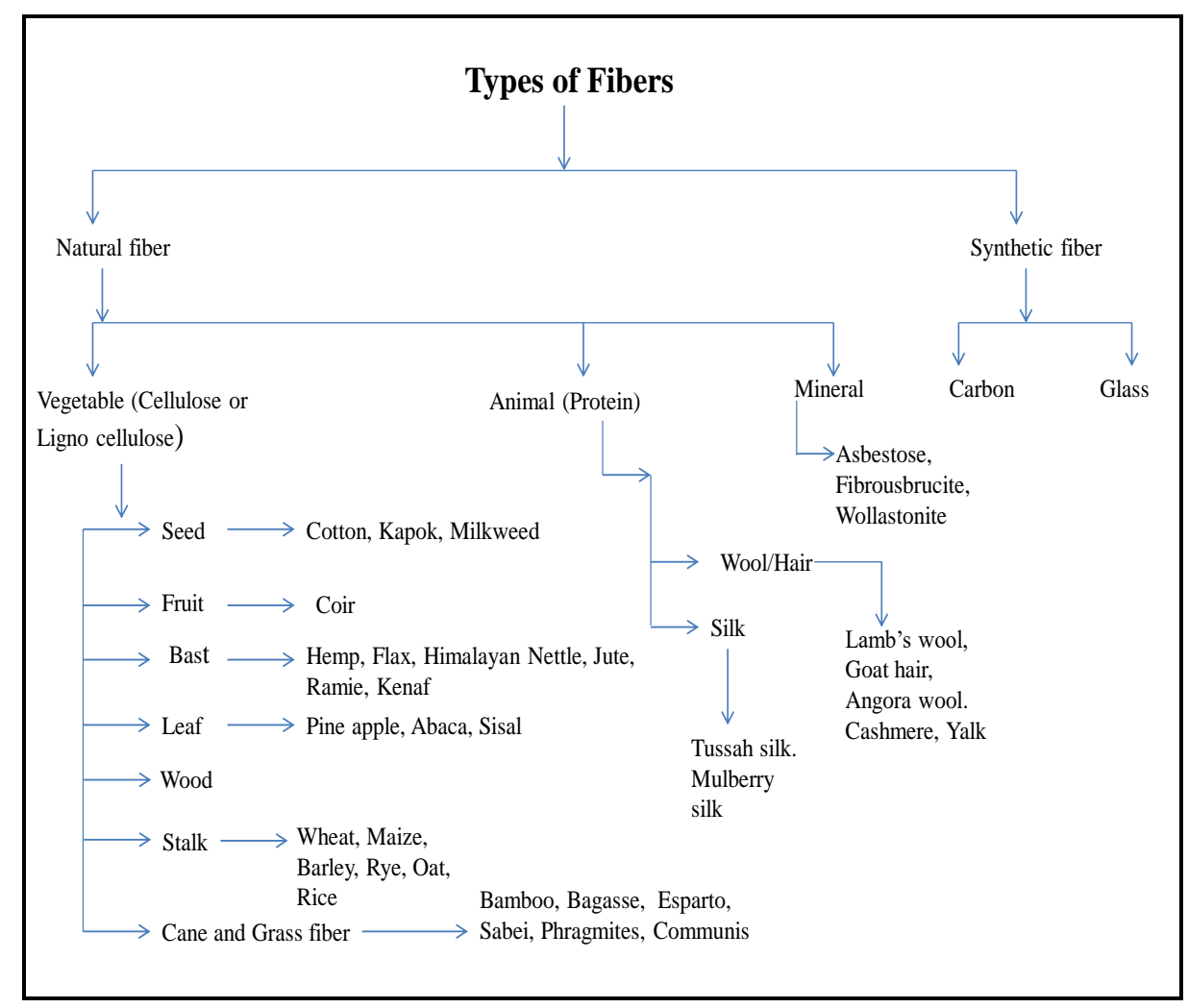

Fig. 3 Classification of natural fibers

Table 1. Mechanical Properties of Natural Fiber and synthetic fiber [49 - 64]

\begin{tabular}{|c|c|c|c|c|}
\hline Fiber & $\begin{array}{c}\text { Tensile strength } \\
(\mathrm{MPa})\end{array}$ & $\begin{array}{c}\text { Elongation at } \\
\text { failure }(\%)\end{array}$ & $\begin{array}{c}\text { Young's Modulus } \\
(\mathrm{GPa})\end{array}$ & $\begin{array}{c}\text { Density } \\
\left(\mathrm{gm} / \mathrm{cm}^{3}\right)\end{array}$ \\
\hline Hemp & 690 & 1.6 & 70 & 1.47 \\
\hline Flax & $345-1500$ & $2.7-3.2$ & 27.6 & 1.5 \\
\hline Sisal & $468-700$ & $3-7$ & $9.4-22$ & 1.45 \\
\hline Ramie & $400-938$ & $1.2-3.8$ & $61.4-128$ & 1.55 \\
\hline Kenaf & $295-1191$ & 1.6 & 53 & $1.3-1.49$ \\
\hline Jute & $393-800$ & $1.16-1.5$ & 30 & 1.3 \\
\hline Spider silk & $1300-2000$ & $28-30$ & $4-6$ & $1.5-1.46$ \\
\hline Coir & $131-220$ & $15-40$ & $5.5-12.6$ & 1.2 \\
\hline Cotton & $287-800$ & $7-8$ & $10.1-16.3$ & $0.6-1.1$ \\
\hline Henequen & $430-570$ & $3.7-5.9$ & $11-17$ & 1.3 \\
\hline Bamboo & $140-230$ & $2.5-3.7$ & $2.3-5$ & 0.9 \\
\hline Wool & $50-315$ & $13.5-35$ & $3-10$ & 1.78 \\
\hline Feather & $100-203$ & 6.9 & 425 & \\
\hline Carbon & 3400 & $1.4-1.8$ & & \\
\hline
\end{tabular}




\begin{tabular}{|c|c|c|c|c|}
\hline Kevlar & 3000 & $2.5-3.7$ & 60 & 1.44 \\
\hline E glass & 3400 & 2.5 & 73 & 2.55 \\
\hline
\end{tabular}

Table 2. Chemical Properties of Natural Fiber [65 - 73]

\begin{tabular}{|c|c|c|c|c|c|c|c|}
\hline $\begin{array}{c}\text { Name of plant } \\
\text { fiber }\end{array}$ & $\begin{array}{c}\text { Hemicellulose } \\
(\%)\end{array}$ & $\begin{array}{c}\text { Moisture } \\
(\%)\end{array}$ & $\begin{array}{c}\text { Cellulose } \\
(\%)\end{array}$ & $\begin{array}{c}\text { Lignin } \\
(\%)\end{array}$ & $\begin{array}{c}\text { Ash } \\
(\%)\end{array}$ & $\begin{array}{c}\text { Pectin } \\
(\%)\end{array}$ & $\begin{array}{c}\text { Wax } \\
(\%)\end{array}$ \\
\hline Banana & $10.2-15.9$ & $2-3$ & $48-60$ & $14.4-21.6$ & 2.1 & $2.1-4.1$ & $3-5$ \\
\hline Betelnut & $29-33.1$ & NA & $35-64.8$ & $13-26$ & $1.1-2.1$ & $9.2-15.4$ & $0.5-0.7$ \\
\hline Bagasse & $20-36.3$ & NA & $28.3-55$ & $21.2-24$ & $1-4$ & NA & 0.9 \\
\hline Bamboo & $12.5-73.3$ & 11.7 & $48.2-73.8$ & $10.2-21.4$ & 2.3 & 0.37 & NA \\
\hline Flax & 16.7 & 10 & 64.1 & 2 & 13.1 & 1.8 & 1.5 \\
\hline Henequen & $4-8$ & NA & 77.6 & 13.1 & NA & NA & NA \\
\hline Jute & 12 & 10 & 64.4 & 0.2 & $0.5-2.1$ & 11.8 & 0.5 \\
\hline Oil Palm & $17.1-33.5$ & NA & $42.7-65$ & $13.2-25.3$ & $1.3-6.0$ & NA & 0.6 \\
\hline Pineapple & 80.7 & NA & $57.5-74.3$ & $4.4-10.1$ & $0.9-4.7$ & 1.1 & 3.3 \\
\hline Ramie & 13.1 & 10 & 68.6 & 0.6 & NA & 1.9 & 0.3 \\
\hline Rice husk & $12-20$ & - & $38-45$ & - & 20 & - & - \\
\hline Sea grass & 38 & - & 57 & 5 & - & 10 & - \\
\hline Sisal & 12.0 & 10 & 65.8 & 9.9 & 4.2 & 0.8 & 0.3 \\
\hline Kenaf & $18-24$ & NA & $37-49$ & $15-21$ & $2.4-5.1$ & 8.9 & 0.5 \\
\hline Hemp & $12-22.4$ & 6.5 & $55-80.2$ & $2.6-13$ & $0.5-0.8$ & $0.9-3.0$ & 0.2 \\
\hline Curaua & 9.9 & NA & 73.6 & 7.5 & NA & NA & NA \\
\hline Cotton & 5.7 & 10 & 82.7 & 28.2 & NA & 5.7 & 0.6 \\
\hline Coir & $11.9-15.4$ & $0.2-0.5$ & $19.9-36.7$ & $32.7-53.3$ & NA & $4.7-7.0$ & NA \\
\hline
\end{tabular}

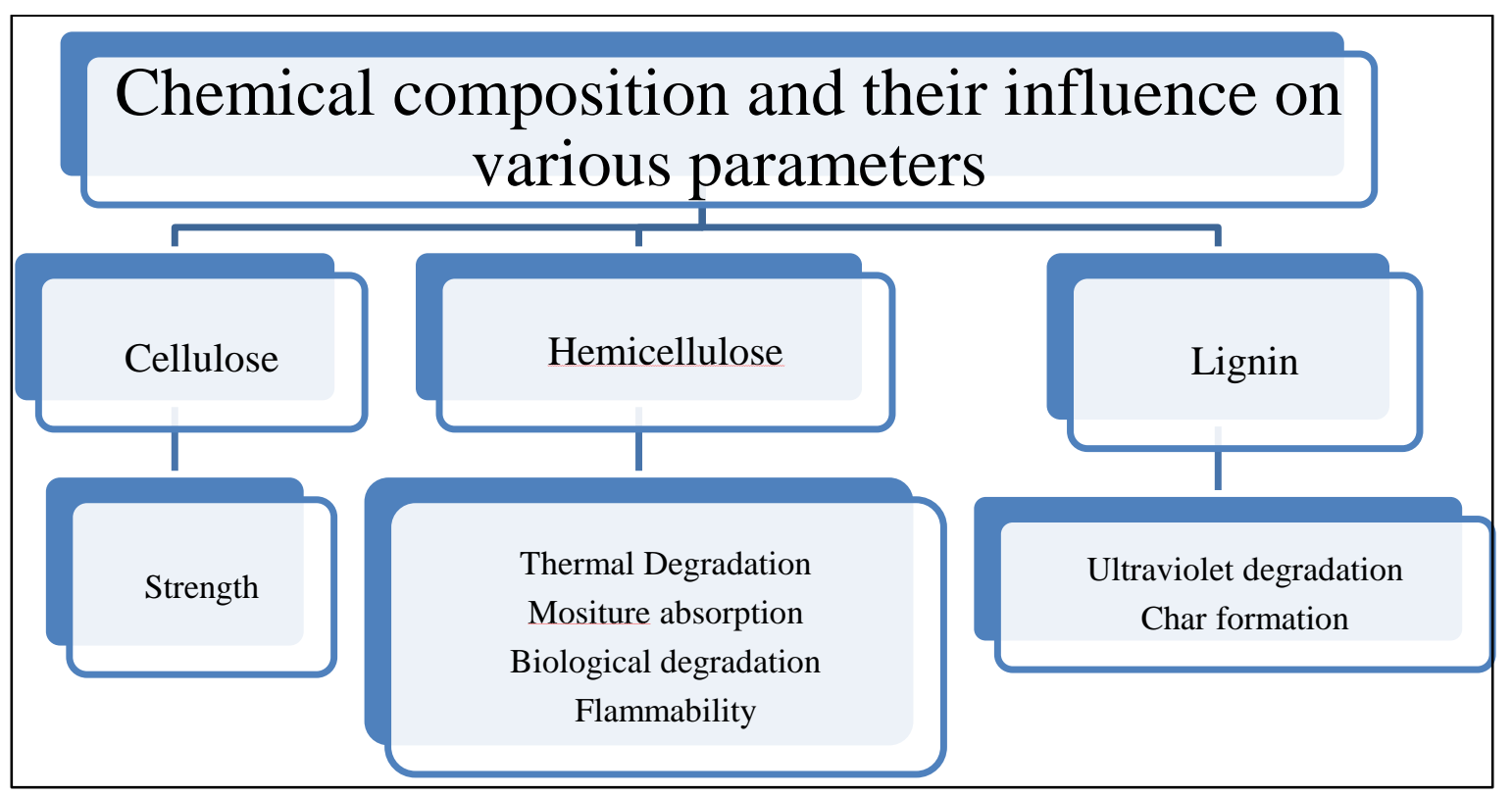

Fig. 4 Chemical composition of fiber [69]

\section{Bio Polymer Matrix}

Biodegradable polymers are called bio polymer. Biopolymer can be formed either by renewable or by synthetic source. The commonly known bio polymers are described in figure 5. Starch, sugar, cellulose and synthetic materials are the four main types of biopolymer. They can also be classified as a) Proteins b) Bio-polyesters by direct fermentation c) Polysaccharides and d) Biopolymers which are found in nature itself. Bio polymers are not 
found straight from the earth, besides there are ways to transform the natural polymer into bio polymer. These are: (a) Modification of naturally occurring polymers for eg. Cellulose derivatives and thermoplastic starch. (b) By using technique fermentation and polymerization to produce bio base monomer for eg. polylactic acid (PLA) and bio-based nylon 6. (c) Using genetically modified crop to produce bio base polymer for eg. poly hydroxyl alkanoates. Various techniques are also available to produce bio polymer such as drying, extrusion, film blowing, wet milling, thermoforming, injection molding, foaming, hydrolysis \& fermentation. These bio polymers are finding their place in market such as for packaging of agriculture material and for tyres filler for cars. Starch is now being used as biopolymer which has a potential to replace polyolefins. PLA which is also a derived bio polymer is already in use and have the potential to replace Poly (methyl methacrylate) (PMMA) [33]. Research is also going on to consider cashew nut shell liquid resin (CNSL) as a biopolymer resin. These biopolymers have significant applications in transport, medicine and textile industries also.

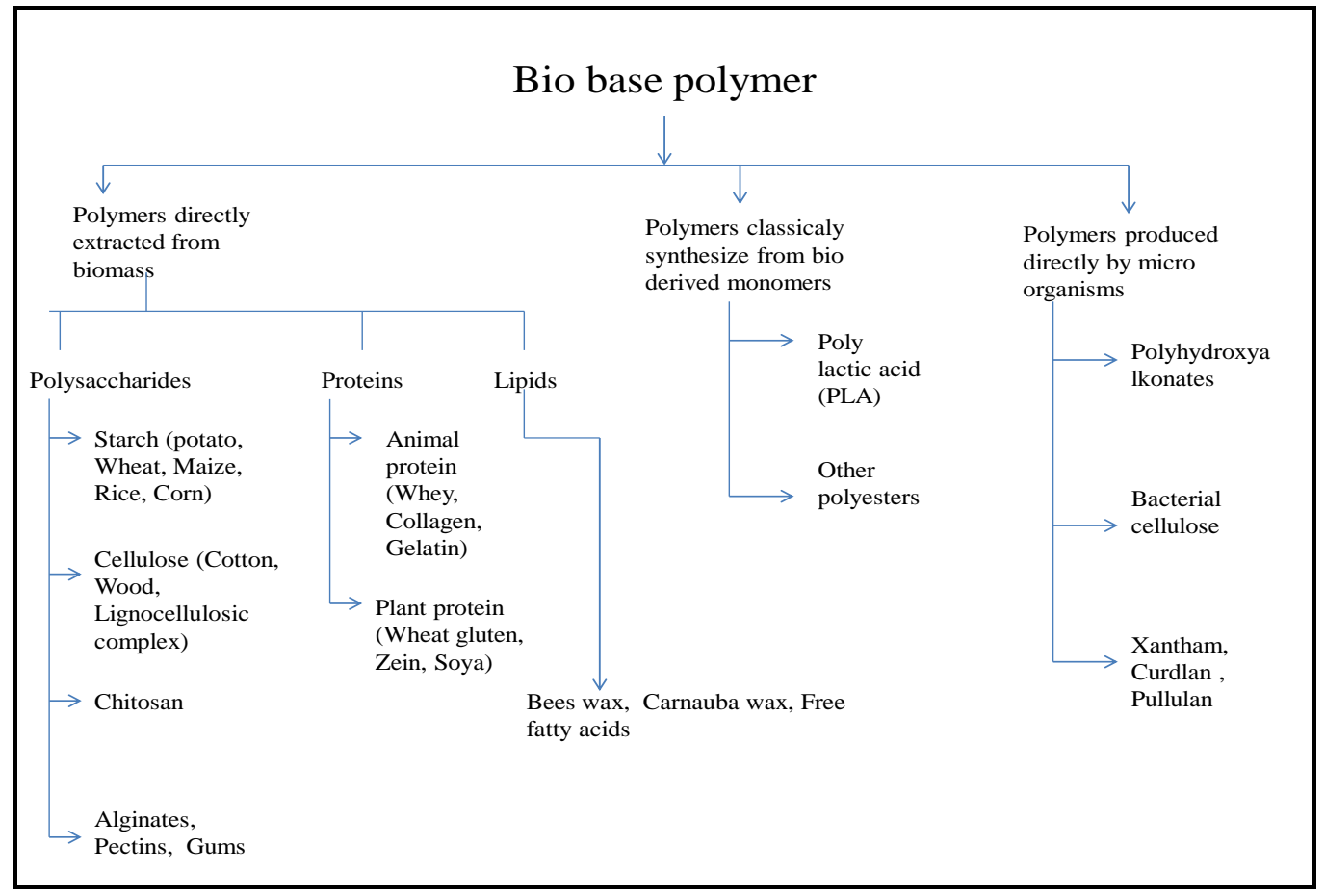

Fig. 5 Classifications of Bio Polymers

\section{Fiber-Matrix Interface}

Fiber matrix interface plays very important role in deciding the mechanical properties of the final composite which is called interfacial shear strength [IFSS]. The stress produced in the composite is transfer through the interface thus a strong bonding is required to hold the bond between fiber and matrix. It is sometime possible to attain the strong bonding between fiber and matrix but the propagation of crack can decrease the IFSS. The equation somehow altered in case of plant fiber due to the hydrophilic nature of plant fiber and hydrophobic nature of polymer. This leads to poor interfacial bonding between fiber and matrix. This hydrophilic nature of plant fiber has been probable reason for the poor bonding which can be improved by the physical and chemical treatment of the fiber [34-38]. Various properties of the composite like transverse mechanical properties, toughness, and interlaminar shear strength (ILSS) can be controlled by IFSS however tensile strength of the composite can be improved by physicochemical, mechanical (interlocking) and chemical interaction. For the development of strong composite good interfacial adhesion is required which maintain the 
structural integrity however energy absorption capability can be improved by weak interfacial bonding. For natural fibers, the IFSS of the fiber/resin can be measured by microbead test.

\section{$5 \quad$ Modification of Natural fibers}

New natural fiber based composites are being developed through the fundamental knowledge of fiber surface. The surface is influenced by polymer morphology, extractive chemicals and processing conditions. There are two types of method to improve the fiber surface, physical and chemical methods. The most familiar treatment of fiber can be seen in figure 6 . Treatment of fiber by physical method includes stretching, calendaring, thermotreatment and production of hybrid yarns. This treatment on the fiber leads to structural and surface changes and thereby enhances the mechanical properties of the fiber. Hydro thermal treatment on Moso bamboo particles reinforced polyvinyl chloride (BP/PVC) at different temperatures $\left(120^{\circ} \mathrm{C}, 140^{\circ} \mathrm{C}, 160^{\circ} \mathrm{C}, 180^{\circ} \mathrm{C}, 200^{\circ} \mathrm{C}, 220^{\circ} \mathrm{C}, 240^{\circ} \mathrm{C}, 260^{\circ} \mathrm{C}\right.$ and $\left.280^{\circ} \mathrm{C}\right)$ was taken which improved the surface property with the removal of hemicelluloses and pectin. Mechanical properties like tensile strength, tensile modulus and flexural strength of the composites was found to be $15.79 \mathrm{MPa}, 6702.26 \mathrm{MPa}$ and $39.57 \mathrm{MPa}$ respectively which was maximum among all elevated temperature due to uniform dispersion of bamboo particles in the polyvinyl chloride matrix whereas elongation at break and flexural deformation was maximum at $200^{\circ} \mathrm{C}$ and $140^{\circ} \mathrm{C}$ respectively . At $160^{\circ} \mathrm{C}$, compatibility, low moisture absorption and high thermal stability was recorded due to decomposition of hemicelluloses at higher temperature [39]. Further, the surface modification of coconut waste particle $(10-50 \mathrm{wt} \%)$ by PECVD method was done for the preparation of advanced bio based composite materials which involved coating of a thin film of hydrophobic poly (hexafluorobutyl acrylate) (PHFBA) around individual CW particle surfaces. It was observed that Plasma-enhanced chemical vapor deposition (PECVD)-treated $\mathrm{CW}$ particles had much more positive effects on the thermal, mechanical, wettability and flammability properties of composites as analysed by TGA, FTIR, SE, and XRD.PHFBA coated CW can be considered highly hydrophobic. It was clearly seen that chemical treatment or coating with polymer increased the roughness of the $\mathrm{CW}$ surface and more rough and rugged surface was noticed for PHFBA coated CW. Tensile strength was increased in the order of untreated $\mathrm{CW}<\mathrm{NaOH}$ treated $\mathrm{CW}<$ PHFBA coated CW. In case of thermal behaviour, PECVD treatment was more effective [40]. Natural fibers have greater affinity towards water and thus possibility of moisture content in the natural fiber green composite is higher. Various attempts have been made to make natural fibers hydrophobic by treating them by hydrophobic aliphatic and cyclic chemical structures. Surface properties of the fibers can be improved by, de-lignifications, bleaching, de-waxing (de-fatting), acetylation, and chemical grafting, cyno ethylation for properties enhancement.

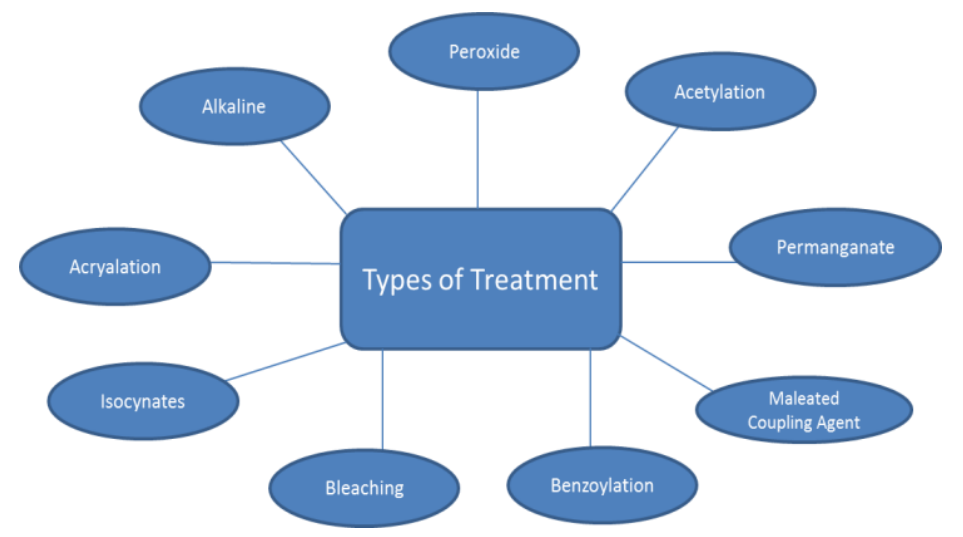

Fig. 6 Classification of treatment applied in Natural fiber 
Impact resistance to fungal attack and hydrophobicity of natural fiber like jute can be achieved by acetylation. This acetylation of jute gives more stability dimensionally. Physical and mechanical characteristics of naturally occurring fiber can also be altered by graft copolymerization in which a suitable polymer is used to enhance the bond between the fiber and the matrix. Increased in ultimate tensile strength is found when the fibers like banana coir, sisal fibers and pine apple leaf fibers are treated with chemicals like sodium alginate and sodium hydroxide [30]. Improved mechanical Properties and reduction in water absorption of jute propylene composite material can also be done by treating with cardanol-formaldehyde. Reduction in moisture absorption is also achieved in case of jute fiber when it is treated with ethylene diamine and hydrazine [24]. Apart from surface treatment, compatibilizer or coupling agent are used to effectively transfer the stress at the interface. These coupling agents are typically known as zirconate, titanate coupling agents or silane [32]. Corona method and plasma treatment are such methods which can be used to change the fiber structurally without using chemical agents [28]. Another process like steam stabilization is used to stabilize the fibers in normal condition when they are heat treated [31]. Various processes involved in the treatment of natural fibers are given in Table 3. Talking about the tensile strength of the composite a cross examination of PP, PLA and HDPE has been discussed for $\mathrm{NAOH}$ and silane treatment (figure 7). In figure 7 natural fibers like bamboo, ramie and henequen are used with the PP, PLA and HDPE polymers to fabricate the composite. Figure 7 shows that $\mathrm{NaOH}$ treated composite of PLA gives the higher tensile strength when comparing with treatment of silane of composites for both bamboo and ramie fiber. For PP based composites silane treatment gives higher tensile strength and same results for HDPE can be seen in the figure 7.

Table 3. Natural fiber treatment $[32,64,74-80]$

\begin{tabular}{|c|c|c|}
\hline Process & $\begin{array}{c}\text { Natural fiber } \\
\text { used }\end{array}$ & Outcomes \\
\hline $\begin{array}{c}\text { Sodium chlorite } \\
\text { treatment }\end{array}$ & Jute fibers & $\begin{array}{c}\text { Significant improvement in tensile strength } \\
\text { young's modulus and extension at break }\end{array}$ \\
\hline $\begin{array}{c}\text { Treatment with Metha } \\
\text { acrylate }\end{array}$ & Jute fibers & $\begin{array}{c}\text { Improvement in flexural and tensile } \\
\text { strength }\end{array}$ \\
\hline $\begin{array}{c}\text { Silane treatment } \\
\text { Acetylation }\end{array}$ & Flax fibers & $\begin{array}{c}\text { Improvement in hydrophobic and } \\
\text { mechanical properties }\end{array}$ \\
\hline $\begin{array}{c}\text { Mercerization } \\
\text { Flax fibers }\end{array}$ & $\begin{array}{c}\text { Increase in tensile strength and flexural } \\
\text { strength }\end{array}$ \\
\hline Freatment with \\
isocyanate & Flax fibers & $\begin{array}{c}\text { Reduction in moisture regain due to better } \\
\text { interface and improvement in mechanical } \\
\text { properties }\end{array}$ \\
\hline Enzyme & Flax fibers & $\begin{array}{c}\text { Decrease in lignin content from 35\% to } \\
24 \%\end{array}$ \\
\hline Per oxide treatment & Ramie fibers & Decrease in moisture regain \\
\hline Benzoylation & Sisal fibers & $\begin{array}{c}\text { Surface modification and improvement in } \\
\text { hydrophobicity }\end{array}$ \\
\hline
\end{tabular}




\begin{tabular}{|c|c|c|}
\hline Plasma treatment & $\begin{array}{c}\text { Sisal/Hemp } \\
\text { fibers }\end{array}$ & $\begin{array}{c}\text { Surface modification and improvement in } \\
\text { hydrophobicity }\end{array}$ \\
\hline Ozone treatment & pulp & Increased the flexural strength \\
\hline $\begin{array}{c}\text { maleic anhydride } \\
\text { MAPP) treatment }\end{array}$ & fiber/sisal fiber & $\begin{array}{c}\text { Improved the tensile strength of the } \\
\text { composites by the enhanced fibre/matrix } \\
\text { interfacial adhesion }\end{array}$ \\
\hline $\begin{array}{c}\text { lysine-based } \\
\text { diisocyanate (LDI) } \\
\text { Treatment }\end{array}$ & Bamboo fiber & $\begin{array}{c}\text { Moisture absorption reduced and adhesion } \\
\text { between fiber and matrix improved }\end{array}$ \\
\hline $\begin{array}{c}\text { Alkalization (KOH and } \\
\text { NAOH treatment) }\end{array}$ & Coir fiber & $\begin{array}{c}\text { Eliminate open hydroxyl group that tend to } \\
\text { bond with water molecule and also } \\
\text { dissolve hemicelluslose }\end{array}$ \\
\hline
\end{tabular}

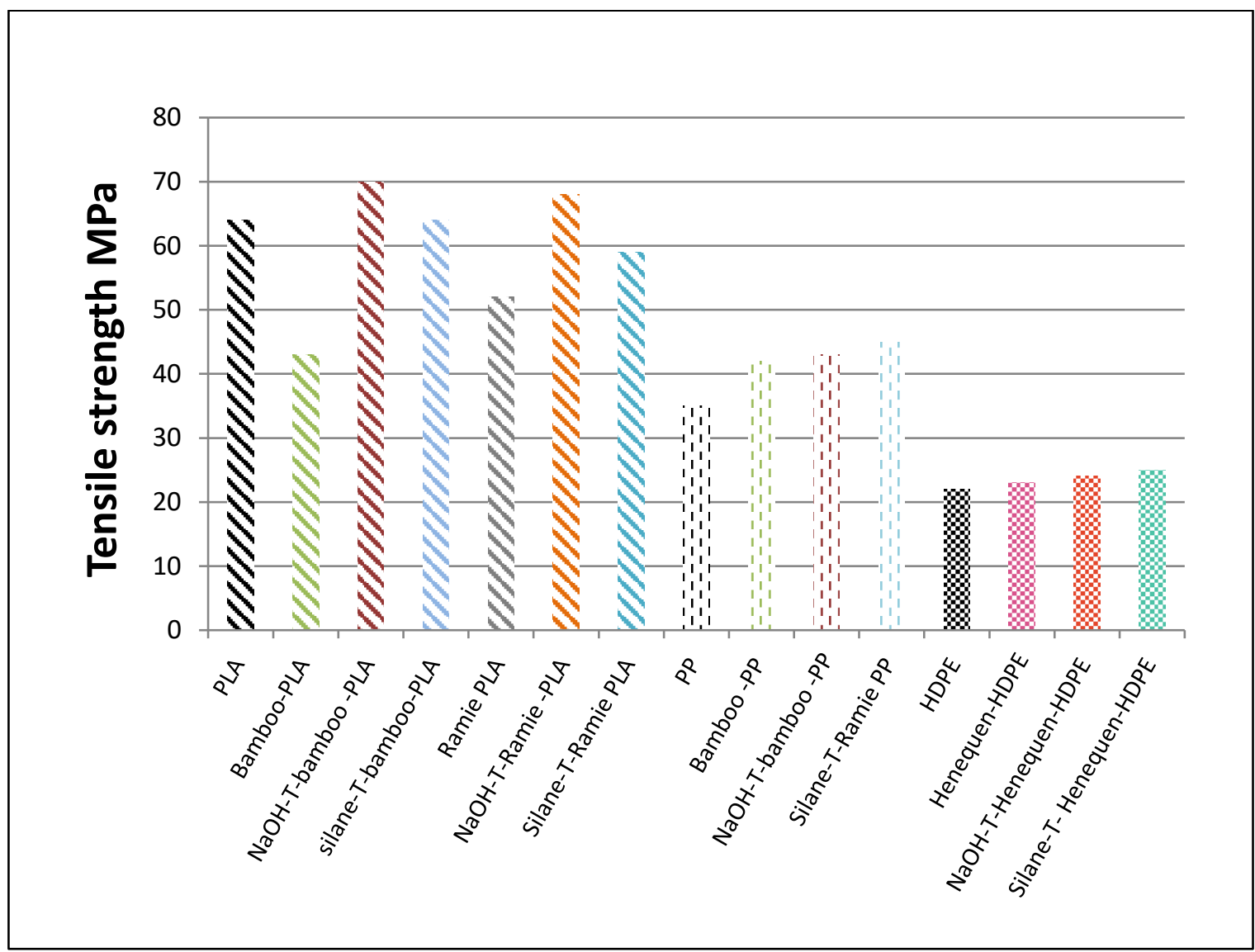

Fig. 7 Tensile strength of natural fiber bio polymer composite and natural fiber polymer composite with treated and untreated fiber [64, 76, 81 - 83]

\section{Green Composites}

Green composite is combination of natural fiber and bio polymer. They have various advantages over polymer composite like biodegradability, environment friendly ease of manufacturing and also possess sufficient mechanical properties due to which finding their place in various sectors such as interior parts of automobiles, casings of electronic products 
etc. Here various combinations of natural fiber and bio polymer and their manufacturing processes are being discussed. Combination of ramie fiber reinforced PLA composite results in considerably increased in notched impact strength [41]. Considerable increase can be found in tensile and bending strength when a kenaf fiber is reinforced with PLA matrix and if the fiber content is increased to $50 \%$ then sufficient increase in young modulus is also achievable [42]. Increased in tensile strength upto $30 \%$ can also be achieved in case of kenaf fiber reinforced PLA composite prepared by melt mixing and injection moulding for $30 \%$ fiber content [43]. Bamboo fiber when mixed with PLA results in increased in bending strength [44]. For hemp fiber PLA composite compression moulding technique can be used which gives remarkably increase in young modulus [45]. Poly (hydroxyl butyrateco-valerates) (PHBV) is another biodegradable polymer obtained from microorganism and has a mechanical properties comparable with conventional thermoplastics such as polyethylene and polypropylene [46]. PHBV when combined with pineapple fiber gives significant increase in tensile and flexural strength [47]. Soy protein is another bio polymer substance can be used as a resin. It has good adhesive property which in turn very useful for the improved mechanical properties for natural fiber composites. Due to its property of ductility soy protein can withstand bending, torsional and tensile deformations without showing any severe damage. Soy protein can be categorized in three types these are soy protein isolate (SPI), soy protein concentrate (SPC) and soy flour. When SPC and SPI are compared with polystyrene it is found that they have comparable tensile stress values when properly cured. Natural fiber like Flax yarn and fabric when combined with SPC for green composite gives improved value of young modulus and tensile failure stress [48]. Further combination can be seen in Table 4 . Thus these combinations of natural fibers and bio polymer composite have good potential to replace non bio degradable composites due to their good mechanical properties.

Table 4. Natural fiber and bio polymer green composite [84 - 98]

\begin{tabular}{|c|c|c|}
\hline $\begin{array}{l}\text { NATURAL FIBER - BIO } \\
\text { POLYMER COMPOSITE }\end{array}$ & PROPERTIES OBTAINED & COMMENTS \\
\hline Kenaf - PLA composite & $\begin{array}{l}\text { Increased in heat resistance and } \\
\text { enhancement in crystallization. }\end{array}$ & $\begin{array}{l}\text { Conventional moulding technique is used } \\
\text { for the manufacturing of composite. }\end{array}$ \\
\hline Sisal- CNSL composites & $\begin{array}{l}\text { Mechanical properties are very } \\
\text { much comparable to sisal- } \\
\text { epoxy and sisal-polyester } \\
\text { Composites. }\end{array}$ & $\begin{array}{l}\text { These composites can be used for roofing } \\
\text { applications. }\end{array}$ \\
\hline sisal-CNSL & $\begin{array}{l}\text { Tensile strengths of } 24.5 \mathrm{MPa} \\
\text { and a Young's modulus of } 8.8 \\
\text { GPa is achieved. }\end{array}$ & $\begin{array}{l}\text { These composites can be used for } \\
\text { packaging of items. Cross linking in the } \\
\text { matrix is achieved }\end{array}$ \\
\hline $\begin{array}{l}\text { Ramie-Soy protein isolate } \\
\text { composite }\end{array}$ & $\begin{array}{l}\text { Resulted in Tensile strength of } \\
81 \mathrm{MPa} \text { and a Young's modulus } \\
\text { of } 200 \mathrm{MPa} \text {. }\end{array}$ & $\begin{array}{l}\text { Increasing the fibre content in the } \\
\text { composite led to higher fracture stress and } \\
\text { Young's moduli, and lower failure strain } \\
\text { percentages. }\end{array}$ \\
\hline Spurn yarn - PLA composite & $\begin{array}{l}\text { Impregnation quality and } \\
\text { dispersion of fiber bundle were } \\
\text { increased. }\end{array}$ & $\begin{array}{l}\text { Compression moulding technique is used at } \\
\text { moulding temperature of } 185^{\circ} \mathrm{C} \text {. }\end{array}$ \\
\hline Bamboo fiber-PLA composite & $\begin{array}{l}\text { Improved Tensile properties, } \\
\text { water resistance, and interfacial } \\
\text { adhesion as compared with the } \\
\text { neat PLA. }\end{array}$ & $\begin{array}{l}\text { Compression moulding technique is used } \\
\text { for the preparation of composite. }\end{array}$ \\
\hline Flax fiber- PLA composite & Increased in tensile strength and & Film stacking is used for the fabrication of \\
\hline
\end{tabular}




\begin{tabular}{|c|c|c|}
\hline & $\begin{array}{l}\text { young modulus when compared } \\
\text { with neat PLA. }\end{array}$ & composite. \\
\hline $\begin{array}{l}\text { Flax fiber mats }(28.5 \%) \\
\text { Sand witch of Flax mat and } \\
\text { Balsa mat -PLA composite }\end{array}$ & $\begin{array}{l}\text { Increase in flexural strength and } \\
\text { shear strength with increasing } \\
\text { temprature of } 180-200^{\circ} \mathrm{C} \text {. }\end{array}$ & $\begin{array}{l}\text { Vaccum bag moulding is used for the } \\
\text { fabrication of composite. }\end{array}$ \\
\hline \begin{tabular}{l}
\multicolumn{3}{l}{$\begin{array}{l}\text { Recycled disposable } \\
\text { Chop sticks fibers }\end{array}$} \\
composite
\end{tabular} & $\begin{array}{l}\text { Increase in glass transition } \\
\text { temperature as compared to } \\
\text { pristine one. }\end{array}$ & $\begin{array}{l}\text { Melt mixing is used. Markedly increase in } \\
\text { tensile strength for a fiber content of } 40 \% \text {. }\end{array}$ \\
\hline Hemp fiber-Polylactic acid & $\begin{array}{l}\text { Increased in adhesion force by } \\
100 \% \text { between fiber and matrix. }\end{array}$ & Treated by $5 \% \mathrm{NaOH}$. \\
\hline $\begin{array}{lll}\text { Ground } & \text { coconut } & \text { fiber-PLA } \\
\text { composite } & & \end{array}$ & $\begin{array}{l}\text { Low cost of manufacturing and } \\
\text { increase in adhesion property. }\end{array}$ & Plasto graph is used to prepare the blend. \\
\hline $\begin{array}{l}\text { Coconut fiber reinforced fly ash } \\
\text { geopolymer resin }\end{array}$ & $\begin{array}{l}\text { Increase in the flexural strength, } \\
\text { flexural modulus and fracture } \\
\text { toughness with the increase in } \\
\text { fiber content. }\end{array}$ & $\begin{array}{l}\text { Fiber weight percentage is restricted to } 0.5 \\
\text { wt\% above } 0.5 \text { wt } \% \text { the mechanical } \\
\text { properties starts decreasing due to } \\
\text { formation of voids and fiber } \\
\text { agglomeration. }\end{array}$ \\
\hline $\begin{array}{l}\text { Date palm fiber reinforced starch } \\
\text { base composite }\end{array}$ & $\begin{array}{l}\text { Strength, stiffness, Thermal } \\
\text { stability and biodegradation } \\
\text { improved. }\end{array}$ & $\begin{array}{l}\text { composites were preheated and then hot } \\
\text { pressed at } 5 \mathrm{MPa} \text { and } 160^{\circ} \mathrm{C} \text { for } 30 \mathrm{~min} \text {. }\end{array}$ \\
\hline Areca fiber- corn starch matrix & $\begin{array}{l}\text { Adhesion increases between } \\
\text { fiber and matrix and reduction } \\
\text { in moisture sorption. }\end{array}$ & Fiber is treated with alkali solution. \\
\hline Jute-PLA composite & $\begin{array}{l}\text { Enhancement of tensile and } \\
\text { flexural properties and } \\
\text { reduction in impact strength. }\end{array}$ & $\begin{array}{l}\text { Fiber is treated with alkali and } \\
\text { permanganate solution. }\end{array}$ \\
\hline $\begin{array}{l}\text { Coconut fiber- wheat guleten } \\
\text { resin composite }\end{array}$ & $\begin{array}{l}\text { Improves interfacial adhesion } \\
\text { between fiber and matrix. }\end{array}$ & $\begin{array}{l}\text { (3-triethoxysilylpropyl)-t-butylcarbamate is } \\
\text { used for silane treatment }\end{array}$ \\
\hline $\begin{array}{lr}\text { Jute fiber- } & \text { PHB } \\
\text { (polyhydroxybutyrate) } & \text { matrix } \\
\text { compsoite } & \end{array}$ & $\begin{array}{l}\text { Flexural modulus and stiffness } \\
\text { increases due to the higher level } \\
\text { of hydrogen bonding as the } \\
\text { percentage of fiber increases. }\end{array}$ & $\begin{array}{l}\text { Bio composite is prepared by twin screw } \\
\text { extrusion process. }\end{array}$ \\
\hline
\end{tabular}

\section{CONCLUSION}

Presently Green composites can be developed at an affordable cost with comparable mechanical properties with non-biodegradable composites and can maintain a balance between ecology, economy and technology. This can help to replace the petroleum based composites which eventually results in consumer benefit. Options are also available in natural fibers to be used with bio polymers for the best sustainable green composite. Consequently development in the field of green composite can be seen in the domain of green composite in the past years.

\section{REFERENCES}

[1] H. P. Raturi, L. Prasad, M. Pokhriyal, V. Tirth. An Estimating the Effect of Process Parameters on Metal Removal Rate and Surface Roughness in WEDM of Composite Al6063/SiC/A12O3 by Taguchi Method. Journal of Mechanical Engineering Strojnicky časopis 2017 (67), No. 2, 25 - 36. 
[2] V. K. Patel, K. Rani, Mechanical and Wear Properties of Friction Stir Welded 0-6Wt\% nAl2O3 Reinforced Al-13Wt\% Si Composites. Journal of Mechanical Engineering Strojnicky casopis 2017 (67), No. 1, 77 - 86.

[3] D. D. Stokke, Q. Wu, G. Han. Introduction to Wood and Natural Fiber Composites. John Wiley \& Sons, West Sussex, UK. 2014

[4] T. Vaisanen, O. Das, L. Tomppo. A review On new bio-based constituents for natural fiber -polymer composites. Journal of Cleaner Production 2017 (149), 582 - 596.

[5] M. Bassyouni, S. Waheed Ul Hasan. The use of rice Straw and husk fibers as reinforcements in composites. In: Faruk, O., Sain, M. (Eds.), Biofiber Reinforcement in Composite Materials. Woodhead Publishing, Cambridge, UK, 2015, 385-422.

[6] Y. El-Shekeil, S. Sapuan, K. Abdan, E. Zainudin. Influence of fiber content on the mechanical and thermal properties of Kenaf fiber rein forced thermoplastic polyurethane composites. Mater. Des. 2012 (40), 299 - 303.

[7] E. Zini, M. Scandola. Green composites: an overview. Polym. Compos. 2011 (12), 1905 $-1915$.

[8] M. Ramesh, K. Palanikumar, K. R. Hemachandra. Plant fibre based bio-composites: Sustainable and renewable green materials. Renewable and Sustainable Energy Reviews 2017 (79), 558 - 584.

[9] K. F. Adekunle. Surface treatments of natural fibres- a review: Part1. Op. J. Org. Polym. Mat. 2015 (3), 41 - 46.

[10] Biopolymer Production for (petro) chemical sector -IEA Technology Perspectives, IEA, 2008.

[11] V. S. Sreenivasan, N. Rajini, A. Alavudeen, V. Arumugaprabu. Dynamic mechanical and thermo-gravimetric analysis of Sansevieria cylindrica/polyester composite: Effect of fiber length, fiber loading and chemical treatment. Composites Part B: Engineering 2015 (69), 76 - 86.

[12] A. B. Nurfatimah, C. Y. Chee, L. A. Abdullah, C. T. Ratnam, N. A. Ibrahim. Thermal and dynamic mechanical properties of grafted kenaf filled poly (vinyl chloride)/ethylene vinyl acetate composites. Materials \& Design (1980-2015) 2015 (65), 204 - 211.

[13] T. Sullins, S. Pillay, A. Komus, H. Ning. Hemp fiber reinforced polypropylene composites: The effects of material treatments. Composites Part B: Engineering 2017 (114), 15 - 22.

[14] E. Rojo, M. V. Alonso, M. Oliet, B. D. Saz-Orozco, F. Rodriguez. Effect of fiber loading on the properties of treated cellulose fiber-reinforced phenolic composites. Composites Part B: Engineering 2015 (68), 185 - 192.

[15] M. Cai, H. Takagi, A. N. Nakagaito, L. Yan, G. IN. Waterhouse. Effect of alkali treatment on interfacial bonding in abaca fiber-reinforced composites. Composites Part A: Applied Science and Manufacturing 2016 (90), 589 - 597.

[16] S. Kocaman, M. Karaman, M. Gursoy, G. Ahmetli. Chemical and plasma surface modification of lignocellulose coconut waste for the preparation of advanced biobased composite materials. Carbohydrate polymers 2017 (159), 48 - 57.

[17] G. C. M. Kumar, A study of short areca fibre reinforced PF composites. in: Proceedings of the World Congress on Engineering WCE , London, 2-4 July 2008, 2008. 
[18] N. H. Padmaraj, M. V. Kini, B. R. Pai, B. S. Shenoya. Development of Short Areca Fiber Reinforced Biodegradable Composite Material. Procedia Engineering 2013 (64), $966-972$.

[19] H. M. Akil, M. F. Omar, A. A. M. Mazuki, S. Safiee, Z. A. M. Ishak, A. A. Bakar. Kenaf fibre reinforced composites: a review. Mater Des. 2011 (32), 4107 - 4121.

[20] M. Ramesh. Kenaf (Hibiscus cannabinus L.) fibre based bio-materials: a review on processing and properties. Prog Mater Sci 2016 (78 - 79), 1 - 92.

[21] N. Venkateshwaran, A. Elayaperumal. Banana fibre reinforced polymer composites A Review. J Reinf Plast Compos 2010 (29), No. 10, 2387 - 2396.

[22] A. Shahzad. Hemp fibre and its composites-A review. J Compos Mater 2012 (46), 973 986.

[23] W. B. Kusumaningrum, S. S. Munawar. Prospect of bio-pelletas an alternative energy to substitute solid fuel based. Energy Procedia 2014 (47), 303 - 309.

[24] M. K. Gupta, R. K. Srivastava, H. Bisaria. Potential of jute fibre reinforced polymer composites: a review. Int J Fib Tex Res. 2015 (5), 30 - 38.

[25] P. Zakikhani, R. Zahari, M. T. H. Sultan, D. L. Majid. Bamboofibre extraction and its reinforced polymer composite material. Int J Chem. Mol. Nucl. Mater Metall Eng. 2014 (8), No. 4, $315-318$.

[26] S. Shinoj, R. Viswanathan, S. Panigrahi, M. Kochubabu. Oil palmfibre (OPF) and its composites: a review. Ind Crop Prod. 2011 (33), 7 - 22.

[27] K. Nanthaya, T. Amornsakchai. A new approach to "Greening" plastic composites using pineapple leaf waste for performance and cost effectiveness. Materials and Design 2014 (55), 292 - 299.

[28] M. Pokhriyal, L. Prasad, H. P. Raturi. An experimental investigation on mechanical and tribological properties of Himalayan nettle fiber composite. Journal of Natural Fibers 2017, 1 - 10. DOI: 10.1080/15440478.2017.1364202.

[29] E. M. Fernandes, J. F. Mano, R. L. Reis. Hybrid cork-polymer composites containing sisal fibre: Morphology, effect of the fibre treatment on the mechanical properties and tensile failure prediction. Composite Structures 2013 (105), 153 - 162.

[30] U. Nirmal, M. M. H. Jamil, M. Ahmad. A review on tribological performance of natural fibre polymeric composites. Tribol Inter. 2015 (83), 77 - 104.

[31] F. Ahmad, H. S. Choi, M. K. Park. A review: natural fiber composites selection in view of mechanical, light weight, and economic properties. Macro Mater Eng. 2015 (300), 10 -24 .

[32] D. B. Dittenber, H. V. S. GangaRao. Critical review of recent publications on use of natural composites in infrastructure. Composites Part A 2011 (43), No. 8, 1419 - 1429.

[33] B. C. Mitra. Environment Friendly Composite Materials: Biocomposites and Green Composites. Defence Science Journal 2014 (64), No. 3, 244 - 261. DOI: 10.14429/dsj.64.7323.

[34] P. Chen, C. Lu, Q. Yu, Y. Gao, J. Li, X. Li. Influence of fiber wettability on the interfacial adhesion of continuous fiber-reinforced PPESK composite. J Appl Polym Sci 2006 (102), No. 3, $2544-2551$. 
[35] X.F. Wu, Y.A. Dzenis. Droplet on a fiber: geometrical shape and contact angle. Acta Mech. 2006 (185), No. 3 - 4, 215 - 225.

[36] Q. Bénard, M. Fois, M. Grisel. Roughness and fibre reinforcement effect onto wettability of composite surfaces. Appl Surf Sci. 2007 (253), No. 10, 4753 - 4758.

[37] E. Sinha, S. Panigrahi. Effect of plasma treatment on structure, wettability of jute fiber and flexural strength of its composite. J Compos Mater. 2009 (43), No. 17, 1791 - 1802.

[38] Z. T. Liu, C. Sun, Z. W. Liu, J. Lu. Adjustable wettability of methyl methacrylate modified ramie fiber. J Appl Polym Sci. 2008 (109), No. 5, 2888 - 2894.

[39] S. Qian, H. Wang, E. Zarei, K. Sheng. Effect of hydrothermal pretreatment on the properties of moso bamboo particles reinforced polyvinyl chloride composites. Composites Part B: Engineering 2015 (82), 23 - 29.

[40] S. Kocaman, M. Karaman, M. Gursoy, G. Ahmetli. Chemical and plasma surface modification of lignocellulose coconut waste for the preparation of advanced biobased composite materials. Carbohydrate polymers 2017 (159), 48 - 57.

[41] Anonymous. Bioplastics in automotive applications, Bioplastics Mag. 2007 (2), No. 1, 4 -8 .

[42] S. Ochi, Mechanical properties of kenaf fibers and kenaf/ PLA composites. Mech. Mater. 2008 (40), No. 4-5, 446- 452.

[43] P. Pan, B. Zhu, W. Kai, S. Serizawa, M. Iji, Y. Inoue. Crystallization behavior and mechanical properties ofbio-basedgreen composites based on poly (lactide) and kenaf fiber. J. Appl. Polym. Sci. 2007 (105), No. 3, 1511 - 1520.

[44] R. Tokoro, D. M. Vu, K. Okubo, T. Tanaka, T. Fujii, T. Fujiura. How to improve mechanical propertiesofpoly lactic acid with bamboo fibers. J. Mater. Sci. 2008 (43), No. 2, $775-787$.

[45] R. Masirek, Z. Kulinski, D. Chionna, E. Piorkowska, M. Pracella. Composites of poly (L-lactide) with hemp fibers: Morphology and thermal and mechanical properties. $J$. Appl. Polym. Sci. 2007 (105), No. 1, 255 - 268.

[46] P. J. Barham, A. Leller. The relationship between microstructure and mode of fracture in polyhydroxybutyrate. J. Polym. Sci. Pol. Phys. 1986 (24), No. 1, 69 - 77.

[47] K. Das, D. Ray, C. Banerjee, N. R. Bandopadhyay, S. Sahoo, A. K. Mohanty, M. Misra. Physio mechanical and thermal properties of jute-nanofiber-reinforced bio copolyester composites. Ind. Eng.Chem.Res. 2010 (49), No. 6, 2775 - 2782.

[48] X. Huang, A. N. Netravali. Characterization of flaxfiber reinforced soy protein resin based green composites modified with nano-clay particles. Compos. Sci. Technol. 2007 (67), No. 10, 2005 - 2014.

[49] D. U. Shah, D. Porter, F. Vollrath. Can silk become an effective reinforcing fibre? A property comparison with flax and glass reinforced composites. Compos Sci Technol. 2014 (101), 173 - 183.

[50] A. Mustafa, M. F. B. Abdollah, F. F. Shuhimi, N. Ismail, H. Amiruddin, N. Umehara. Selection and verification of kenaf fibres as an alt ernative friction material using Weighted Decision Matrix method. Mater Des. 2015 (67), 577 - 582. 
[51] I. M. De Rosa, J. M. Kenny, D. Puglia, C. Santulli, F. Sarasini. Tensile behaviour of New Zealand flax (Phormium tenax) fibers. J Reinf Plast Compos. 2010 (29), No. 23, $3450-3454$.

[52] D. B. Dittenber, H. V. S. GangaRao. Critical review of recent publications on use of natural composites in infrastructure. Composites Part A 2011 (43), No. 8, 1419 - 1429.

[53] E. Zini, M. Scandola. Green composites: an overview. Polym Compos. 2011 (32), No. $12,1905-1915$.

[54] N. Reddy, Q. R. Jiang, Y.Q. Yang. Biocompatible natural silk fibers from Argema mittrei. J Biobased Mater Bioenergy 2012 (6), No. 5, 558 - 563.

[55] T. M. Le, K. L. Pickering. The potential of harakeke fibre as reinforcement in polymer matrix composites including modelling of long harakeke fibre composite strength. Composites Part A: Applied Science and Manufacturing 2015 (76), 44 - 53.

[56] K. Pickering. Properties and performance of natural-fibre composites. Cambridge, England: Woodhead Publishing, 2008.

[57] S. Cheng, K. T. Lau, T. Liu, Y. Zhao, P. M. Lam, Y. Yin. Mechanical and thermal properties of chicken feather fiber/PLA green composites. Composites Part B: Engineering 2009 (40), No. 7, 650 - 654.

[58] M. P. Gashti. Effect of colloidal dispersion of clay on some properties of wool fiber. $J$ Dispersion Sci Technol. 2013 (34), No. 6, 853 - 858.

[59] M. Niu, X. Liu, J. Dai, W. Hou, L. Wei, B. Xu. Molecular structure and properties of wool fiber surface-grafted with nano-antibacterial materials. Spectrochim Acta Part A Mol Biomol Spectrosc. 2012 (86), 289 - 293.

[60] M. Zhan, R. P. Wool. Mechanical properties of chicken feather fibers. Polym Compos. 2011 (32), No. 6, 937 - 944.

[61] M. A. Efendy, K. L. Pickering. Comparison of harakeke with hemp fibre as a potential reinforcement in composites. Composites Part A: Applied Science and Manufacturing 2014 (67), 259 - 267.

[62] H. Y. Cheung, M. P. Ho, K. T. Lau, F. Cardona, D. Hui. Natural fibre-reinforced composites for bioengineering and environmental engineering applications. Composites Part B: Engineering 2009 (40), No. 7, 655 - 663.

[63] L. Yan, N. Chouw, K. Jayaraman. Flax fibre and its composites-a review. Composites Part B: Engineering 2014 (56), 296 - 317.

[64] G. A. Khan, M. Shaheruzzaman, M. H. Rahman, S. A. Razzaque, M. S. Islam, M. S. Alam. Surface modification of okra bast fiber and its physico-chemical characteristics. Fibers and polymers 2009 (10), No. 1, 65 - 70.

[65] A. P. Mathew, K. Oksman, Z. Karim, P. Liu, S. A. Khan, N. Naseri. Process scale up and characterization of wood cellulose nanocrystals hydrolysed using bioethanol pilot plant. Industrial crops and products 2014 (58), 212 - 219.

[66] Z. Karim, A. P. Mathew, M. Grahn, J. Mouzon, K. Oksman. Nanoporous membranes with cellulose nanocrystals as functional entity in chitosan: removal of dyes from water. Carbohydrate polymers 2014 (112), 668 - 676. 
[67] Z. Karim, S. Claudpierre, M. Grahn, K. Oksman, A. P. Mathew. Nanocellulose based functional membranes for water cleaning: Tailoring of mechanical properties, porosity and metal ion capture. Journal of Membrane Science 2016 (514), 418 - 428.

[68] Z. N. Azwa, B. F. Yousif, A. C. Manalo, W. Karunasena. A review on the degradability of polymeric composites based on natural fibres. Materials \& Design 2013 (47), 424 442 .

[69] O. Faruk, A. K. Bledzki, H. P. Fink, M. Sain. Progress report on natural fiber reinforced composites. Macromolecular Materials and Engineering 2014 (299), No. 1, 9 - 26.

[70] Z. Karim, A. P. Mathew, K. Oksman, M. Grahn. Fully biobased nanocomposite membranes: removal of heavy metals from polluted water. In Dissemination Workshop for the Nano4water Cluster: 23/04/2014-24/04/2014, 2014.

[71] Z. Karim, A. P. Mathew, V. Kokol, J. Wei. Grahn, M. High-flux affinity membranes based on cellulose nanocomposites for removal of heavy metal ions from industrial effluents. RSC Advances 2016 (6), No. 25, 20644 - 20653.

[72] Z. Karim, M. Hakalahti, T. Tammelin, A. Mathew, K. Oksman. Effect of in situ TEMPO surface functionalization of nanocellulose membranes on the adsorption of metal ions from aqueous solution. RSC Advances 2016

[73] A. Etaati, H. Wang, S. Pather, Z. Yan, S. A. Mehdizadeh. 3D X-ray microtomography study on fibre breakage in noil hemp fibre reinforced polypropylene composites. Composites Part B: Engineering 2013 (50), 239 - 246.

[74] S. H. Lee, S. Wang. Biodegradable polymers/bamboo fiber biocomposite with biobased coupling agent. Composites Part A: Applied Science and Manufacturing 2006 (37), No. 1, 80-91.

[75] V. K. Thakur, M. K. Thakur, R. K. Gupta. Graft copolymers of natural fibers for green composites. Carbohydrate polymers 2014 (104), 87 - 93.

[76] S. Alix, L. Lebrun, C. Morvan, S. Marais. Study of water behaviour of chemically treated flax fibres-based composites: A way to approach the hydric interface. Composites Science and Technology 2011 (71), No. 6, 893 - 899.

[77] K. M. M. Rao, K. M. Rao. Extraction and tensile properties of natural fibers: Vakka, date and bamboo. Composite structures 2007 (77), No. 3, 288 - 295.

[78] Y. Xie, C. A. Hill, Z. Xiao, H. Militz, C. Mai. Silane coupling agents used for natural fiber/polymer composites: A review. Composites Part A: Applied Science and Manufacturing 2010 (41), No. 7, 806 - 819.

[79] E. M. Fernandes, J. F. Mano, R. L. Reis. Hybrid cork-polymer composites containing sisal fibre: morphology, effect of the fibre treatment on the mechanical properties and tensile failure prediction. Composite Structures 2013 (105), 153 - 162.

[80] T. Yu, J. Ren, S. Li, H. Yuan, Y. Li. Effect of fiber surface-treatments on the properties of poly (lactic acid)/ramie composites. Composites Part A: Applied Science and Manufacturing 2010 (41), No. 4, 499 - 505.

[81] A. Valadez-Gonzalez, J. M. Cervantes-Uc, R. Olayo, P. J. Herrera-Franco. Chemical modification of henequen fibers with an organosilane coupling agent. Composites Part B: Engineering 1999 (30), No. 3, 321 - 331.

[82] N. Graupner, A. S. Herrmann, J. Müssig. Natural and man-made cellulose fibrereinforced poly (lactic acid) (PLA) composites: An overview about mechanical 
characteristics and application areas. Composites Part A: Applied Science and Manufacturing 2009 (40), No. 6, 810 - 821.

[83] S. Ochi. Mechanical properties of kenaf fibers and kenaf/PLA composites. Mechanics of materials 2008 (40), No. 4, 446 - 452.

[84] A. Memon, A. Nakai. Fabrication and mechanical properties of jute spun yarn/PLA unidirection composite by compression molding. Energy Procedia 2013 (34), 830 838.

[85] D. Liu, T. Zhong, P. R. Chang, K. Li, Q. Wu. Starch composites reinforced by bamboo cellulosic crystals. Bioresource technology 2010 (101), No. 7, 2529 - 2536.

[86] J. L. Guimarães, F. Wypych, C. K. Saul, L. P. Ramos, K. G. Satyanarayana. Studies of the processing and characterization of corn starch and its composites with banana and sugarcane fibers from Brazil. Carbohydrate Polymers 2010 (80), No. 1, 130 - 138.

[87] E. Bodros, I. Pillin, N. Montrelay, C. Baley. Could biopolymers reinforced by randomly scattered flax fibre be used in structural applications? Composites Science and Technology 2007 (67), No. 3, $462-470$.

[88] A. Le Duigou, J. M. Deux, P. Davies, C. Baley. PLLA/flax mat/balsa bio-sandwich manufacture and mechanical properties. Applied Composite Materials 2011 (18), No. 5, $421-438$.

[89] M. A. Sawpan, K. L. Pickering, A. Fernyhough. Effect of fibre treatments on interfacial shear strength of hemp fibre reinforced polylactide and unsaturated polyester composites. Composites Part A: Applied Science and Manufacturing 2011 (42), No. 9, $1189-1196$.

[90] C. S. Wu. Renewable resource-based composites of recycled natural fibers and maleated polylactide bioplastic: Characterization and biodegradability. Polymer Degradation and Stability 2009 (94), No. 7, 1076 - 1084.

[91] M. Y. M. Zuhri, Z. W. Guan, W. J. Cantwell. The mechanical properties of natural fibre based honeycomb core materials. Composites Part B: Engineering 2014 (58), 1 - 9.

[92] T. Alomayri, F. U. A. Shaikh, I. M. Low. Characterisation of cotton fibre-reinforced geopolymer composites. Composites Part B: Engineering 2013 (50), 1 - 6.

[93] H. Ibrahim, M. Farag, H. Megahed, S. Mehanny. Characteristics of starch-based biodegradable composites reinforced with date palm and flax fibers. Carbohydrate polymers 2014 (101), 11 - 19.

[94] N. H. Padmaraj, M. V. Kini, B. R. Pai, B. S. Shenoy. Development of short areca fiber reinforced biodegradable composite material. Procedia Engineering 2013 (64), 966 972.

[95] C. V. Srinivasa, K. N. Bharath. Effect of alkali treatment on impact behavior of areca fibers reinforced polymer composites. Fiber composites 2013 (1), No. 2, 8.

[96] B. K. Goriparthi, K. N. S. Suman, N. M. Rao. Effect of fiber surface treatments on mechanical and abrasive wear performance of polylactide/jute composites. Composites Part A: Applied Science and Manufacturing 2012 (43), No. 10, 1800 - 1808.

[97] S. Hemsri, K. Grieco, A. D. Asandei, R. S. Parnas. Wheat gluten composites reinforced with coconut fiber. Composites Part A: Applied Science and Manufacturing 2012 (43), No. 7, $1160-1168$. 
[98] M. A. Gunning, L. M. Geever, J. A. Killion, J. G. Lyons, C. L. Higginbotham. Mechanical and biodegradation performance of short natural fibre polyhydroxybutyrate composites. Polymer Testing 2013 (32), No. 8, 1603 - 1611. 